Check for updates

The BMJ

Cite this as: $B M J 2021 ; 372: n 46$ http://dx.doi.org/10.1136/bmj.n46 Published: 07 January 2021

\section{Covid-19 vaccine: GPs should decide whether to honour second dose appointments, says minister}

Gareth lacobucci

GPs should use their own discretion to decide whether to honour existing appointments to administer second doses of the Pfizer and BioNTech covid vaccine, the minister for covid vaccine deployment, Nadhim Zahawi, has said.

Last week healthcare workers in England were told to reschedule appointments for the second dose of the vaccine after the government's Joint Committee on Vaccination and Immunisation (JCVI) decided that vaccinating as many people as possible with a first dose should be the priority. ${ }^{1}$ The chief medical officers of all four UK nations subsequently wrote to doctors asking them to delay second doses of both the Pfizer-BioNTech vaccine and the Oxford University and AstraZeneca vaccine until 12 weeks after the first. ${ }^{2}$

But the BMA has argued that changing appointments that were already booked is impractical and potentially distressing for patients, while some experts have questioned the lack of evidence for the change. ${ }^{3}$

Zahawi was asked on BBC Radio 4's Today programme on 6 January whether it was wrong for GPs to honour existing appointments and give patients' second doses of the Pfizer vaccine in spite of the advice. ${ }^{4} \mathrm{He}$ replied, "They will make those decisions, ultimately, based on local circumstances, and they're right to have that ability to make those decisions."

Zahawi added, "We have supported them [practices] financially to make those changes in terms of the second dose appointment. We have also supported them to make those phone calls on their behalf to change the appointments."

Anuj Patel, a GP partner at the Wentworth Medical Practice in Finchley, north London, which has set up marquees in the practice's garden to deliver the vaccine to patients from 22 practices across two primary care networks, said his team had been inundated with calls from patients since the order to reschedule appointments was issued.

He told The BMJ, "We're getting so many phone calls from patients saying, 'Are we having our second vaccine? When is it going to be? When are we going to be told?' You almost need to set up a national hotline for the vaccination, because this is not unique to us; this is a national issue. Those sort of things haven't really been thought through."

Patel said it was regrettable that the shift in dosing had created confusion at a time when clear messages to the public were vital.

"The problem is that we're the ones managing the communications with the patients. It's quite hard to keep up with the changing of the goalposts ... and that makes it look like we're not clear about what's going on," he said. "There's quite a lot of panic among the public. We're starting to see people saying, 'Well, if it's not effective after 12 weeks, why am I having the first dose?' Those sorts of things then discourage the uptake, which is not helpful."

Mahase E. Covid-19: Order to reschedule and delay second vaccine dose is “totally unfair," says BMA. BMJ2020;371:m4978. doi: 10.1136/bmj.m4978 pmid: 33384299

2 Department for Health and Social Care. Letter to the profession from the UK chief medical officers regarding the UK covid-19 vaccination programmes. 31 Dec 2020. https://www.gov.uk/government/publications/letter-to-the-profession-from-the-uk-chief-medical-officers-on-the-uk-covid-19-vaccination-programmes/letterto-the-profession-from-the-uk-chief-medical-officers-regarding-the-uk-covid-19-vaccination-programmes.

lacobucci G, Mahase E. Covid-19 vaccination: What's the evidence for extending the dosing interval?BM/2021;372: n18doi: 10.1136/bmj.n18.

Today. BBC. 6 Jan 2021. https://www.bbc.co.uk/programmes/m000qx03. 